\title{
Seasonal variation of bacterial production, respiration and growth efficiency in the open NW Mediterranean Sea
}

\author{
R. Lemée ${ }^{1, *}$, E. Rochelle-Newall ${ }^{1}$, F. Van Wambeke ${ }^{2}$, M.-D. Pizay ${ }^{1}$, P. Rinaldi ${ }^{1}$, \\ J.-P. Gattuso ${ }^{1}$
}

\begin{abstract}
${ }^{1}$ Observatoire Océanologique, Laboratoire d'Océanographie de Villefranche, Equipe ‘Diversité, Biogéochimie et Ecologie Microbienne', UPMC-CNRS UMR 7093, 06234 Villefranche-sur-Mer Cedex, France

${ }^{2}$ Laboratoire de Microbiologie Marine, CNRS UMR 6117, Centre d'Océanologie de Marseille, Campus de Luminy, Case 907, 13288 Marseille Cedex 09, France
\end{abstract}

\begin{abstract}
Bacterial growth efficiency (BGE) can have a major influence on planktonic food web structure and function; however, its controlling factors are poorly understood. Here, we report results from an annual study aimed at examining bacterial respiration (BR), production (BP), biomass (BB) and BGE in the upper $130 \mathrm{~m}$ of the DYFAMED station (JGOFS site, France) in the NW Mediterranean Sea. From the pre-bloom period to early summer, and with a negative gradient from sub-surface to $130 \mathrm{~m}$, bacterial parameters seem to follow each other, i.e. maximum respiration in February, maximum production in March and maximum biomass in April. BGE ranged from 0.1 to $43 \%$ throughout the study period and was highest during the spring bloom and during the fall. These data clearly showed the wide range of BGE that can be experienced at 1 site on an annual timescale in the surface mixed layer and suggest that several factors (concentrations of inorganic nutrients and DOC) control BGE at this site. Our results also suggested that this oligotrophic system is net heterotrophic.
\end{abstract}

KEY WORDS: Bacterial abundance $\cdot$ Bacterial production $\cdot$ Bacterial respiration $\cdot$ Bacterial growth efficiency $\cdot$ NW Mediterranean $\cdot$ DYFAMED

\section{INTRODUCTION}

Bacteria are the most abundant and most important biological component involved in the transformation and mineralization of organic matter in the biosphere. Planktonic heterotrophic bacteria contribute to the carbon cycling in 2 major ways: (1) by the production of new biomass (bacterial secondary production, BP); and (2) by the remineralization of organic carbon (bacterial respiration, BR). However, the magnitude of the flow of organic carbon through bacterioplankton remains largely unknown because measurements of BP are seldom accompanied by measurements of BR (Jahnke \& Craven 1995). Direct measurement of BR is problem-

*E-mail: lemee@obs-vlfr.fr atic because it requires either physical separation of bacteria from other members of plankton, the use of assumptions about the contribution of bacteria to total respiration or the use of selective inhibitors. The lack of knowledge about BR limits our ability to understand the role of bacteria in the carbon cycle of aquatic systems (del Giorgio \& Cole 1998).

More estimations of BP and BR would allow direct calculation of bacterial growth efficiency (BGE), which can simply be considered as the efficiency of conversion of dissolved to particulate organic carbon. Jahkne \& Craven (1995) pointed out the large degree of uncertainty in estimates of BGE. In addition, Cole \& Pace (1995) have argued that the high variability is probably not random and if the causes of this variation are environmental factors (such as nutrient status or type of organic substrate), then ecological information linked 
to this variance would be useful. In a review of BGE in natural aquatic systems, del Giorgio \& Cole (1998) showed a consistent increase in BGE along gradients of productivity in aquatic systems, and this led them to suggest that a combination of the quality of the organic matter, nutrient availability and particular energetic demands in each type of system may regulate BGE.

The aim of this paper is to investigate bacterioplankton processes over a year in an open ocean system in order to establish environmental factors linked to BGE variation. The literature suggests seasonal cycles of bacterial metabolic activity (Pomeroy \& Wiebe 1993, Griffith \& Pomeroy 1995), but few studies have attempted to address seasonal changes in microbial respiratory rates, although such cycles could have a major influence on planktonic food web structure and function (Griffith \& Pomeroy 1995) and on the carbon cycle. We compared seasonal variations of primary production (PP), chlorophyll a (chl a), DOC concentrations, bacterial biomass (BB), bacterial production (BP), community respiration $(\mathrm{CR})$ and bacterial respiration (BR), in the upper water column of the time series station DYFAMED (JGOFS site, France); a site which can be considered as representative of the whole NW Mediterranean Sea (Marty et al. 1994).

\section{MATERIALS AND METHODS}

Study area and sample collection. Samples were collected at approximately monthly intervals at the DYFAMED station located in the central part of the NW Mediterranean Sea $\left(43^{\circ} 25^{\prime}\right.$ N, $7^{\circ} 52^{\prime}$ E; Fig. 1) from

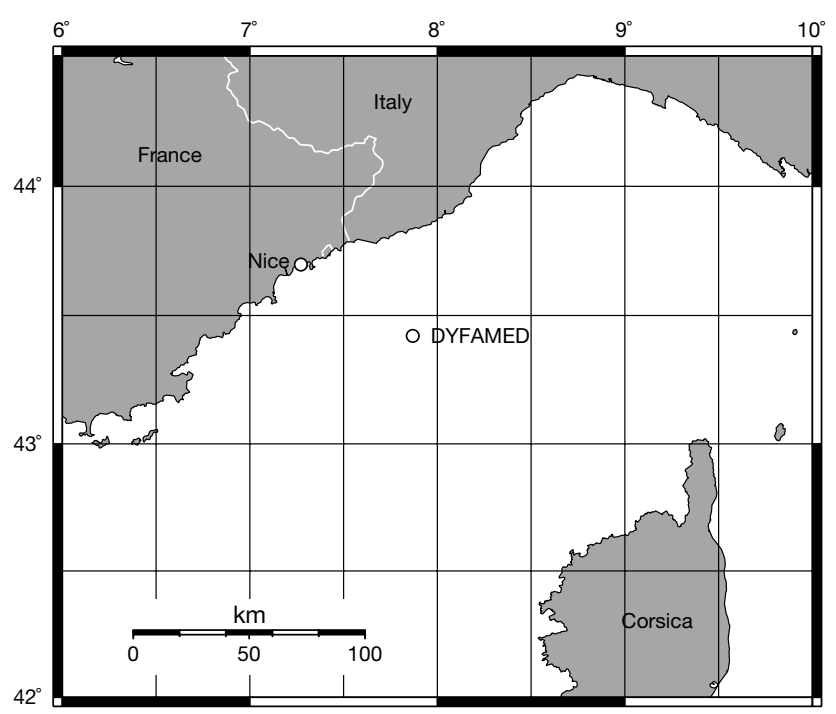

Fig. 1. Location of the study site. Map plotted with online map creation (OMC) available at www.aquarius.geomar.de/omc/
January 1999 to January 2000. Water was sampled between 12:00 and 14:00 h GMT. Sampling was carried out at 5 depths for measurement of bacterial processes (5 m, depth of chl a maximum [DCM], 50, 90 and $130 \mathrm{~m}$ ) using 121 Niskin bottles mounted on a rosette coupled to a Seabird CTD system (SBE 9). Samples were also collected at $20 \mathrm{~m}$ depth when the DCM was close to $50 \mathrm{~m}$.

Determination of nutrient and dissolved organic carbon concentrations. Additional samples were collected at 10 depths between the surface and $130 \mathrm{~m}$ for determination of inorganic nutrients. They were stored in $100 \mathrm{ml}$ polyethylene bottles at $-20^{\circ} \mathrm{C}$ pending analysis in the laboratory. Measurements were carried out using an Alliance-Instrument EV2 AutoAnalyzer as described by Tréguer \& Le Corre (1975).

Samples for DOC analysis were collected in combusted $\left(450^{\circ} \mathrm{C}\right.$ for 4 to $\left.5 \mathrm{~h}\right)$ glass ampoules, flamesealed immediately after collection and stored frozen $\left(-18^{\circ} \mathrm{C}\right)$ until analysis. The samples were not filtered as the POC content of the samples is low at this site (<3.6 $\mu \mathrm{mol} \mathrm{C} \mathrm{l}^{-1}$, Copin-Montégut \& Copin-Montégut 1983) and should not, therefore, contribute significantly to the DOC values. The DOC analysis was performed using high temperature combustion on a Shimadzu TOC-5000 total organic carbon analyzer. A

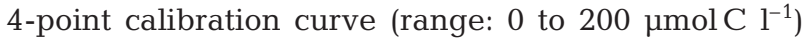
was constructed for each measurement day using potassium phthalate standards prepared fresh in UV treated Milli-Q water. The instrument blank was assessed using 2 external standards (Certified Reference Materials, Hansell Laboratory, Bermuda Biological Station). The instrument blank was between 10

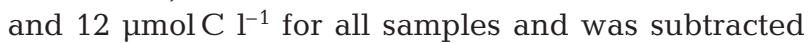
from the measurements. All DOC concentrations reported are the average of 3 injections from each sample.

Chl a concentration and PP. Chl a concentrations were determined by HPLC following the method of Vidussi et al. $(1996,2000) .{ }^{14} \mathrm{C}$ PP was measured at 10 depths between the surface and $90 \mathrm{~m}$ with the selfcontained in situ let go device (Dandonneau \& Le Boutellier 1992). The $250 \mathrm{ml}$ chambers were incubated in situ for $4 \mathrm{~h}$ centered around 12:00 h GMT after addition of $25 \mu \mathrm{Ci}$ of ${ }^{14} \mathrm{C}$ sodium bicarbonate. At the end of the incubation, the water samples were filtered on to glass fiber filters (GF/F, Whatman) and the incorporation of label into the particulate fraction was counted on a Packard Tri-Carb 4000 scintillation counter. The correction factor described by Moutin et al. (1999) was used to convert PP rates obtained during the $4 \mathrm{~h}$ incubations to daily (24 h) rates.

BB and BP. Bacterial abundance was measured by a direct count method using epifluorescent microscopy and DAPI-stained samples (Porter \& Feig 1980). 
Samples $(20 \mathrm{ml})$ were preserved with $0.2 \mu \mathrm{m}$ pore size filtered borax-buffered formalin ( $2 \%$ final concentration) and stored refrigerated in the dark. With the exception of 2 instances, when we had technical problems, slides were prepared within $24 \mathrm{~h}$ of sampling. For each slide, $5 \mathrm{ml}$ of sample were stained with $0.2 \mu \mathrm{m}$ filtered DAPI solution for $10 \mathrm{~min}$ and filtered onto a black $0.2 \mu \mathrm{m}$ pore size Nuclepore membrane filter. Filters were mounted on glass slides with nonfluorescent immersion oil and stored frozen until enumeration. Samples were analyzed in duplicate and at least 10 randomly selected microscope fields on each filter were counted using a Zeiss microscope (magnification 1250×). BB was calculated from the number of bacteria and a carbon content per cell of $15 \mathrm{fg} \mathrm{C}^{\mathrm{C}} \mathrm{cell}^{-1}$ (Caron et al. 1995).

Heterotrophic BP was estimated from the rate of protein synthesis determined by the incorporation of ${ }^{3} \mathrm{H}$ leucine into trichloroacetic acid (TCA) insoluble macromolecular material (Kirchman et al. 1985). Three $20 \mathrm{ml}$ replicates from each depth were spiked with $20 \mathrm{nM}$ of $2 \mathrm{nM}{ }^{3} \mathrm{H}$-leucine, specific activity $150 \mathrm{Ci}$ $\mathrm{mmol}^{-1}$ and $18 \mathrm{nM}$ cold leucine mix and were incubated in the dark at in situ temperatures $\left( \pm 1.5^{\circ} \mathrm{C}\right)$ for $2 \mathrm{~h}$. Preliminary experiments confirmed that leucine incorporation is linear during this period. One of the replicates, to which formalin had been added ( $2 \%$ final concentration) served as a control. The live incubations were terminated with formalin and all samples were filtered onto $0.2 \mu \mathrm{m}, 25 \mathrm{~mm}$ diameter nitrocellulose filters. Samples were then extracted with 5\% TCA for $10 \mathrm{~min}$ followed by five $3 \mathrm{ml}$ rinses with $5 \%$ TCA. The filters were placed in scintillation vials and $20 \mathrm{ml}$ of filter count scintillation cocktail (Packard) was added. Radioactivity was counted with a Beckman LS 1800 counter and the counting efficiency was corrected for quenching. Concentration kinetic experiments showed that isotopic dilution was negligible when using $20 \mathrm{nM}$ leucine. BP rates were then calculated from leucine incorporation rates using the conversion factor of $1.5 \mathrm{~kg} \mathrm{C} \mathrm{mol}^{-1}$ leucine (Kirchman 1993). Daily BP were calculated as 24 times the hourly rates.

CR, BR and BGE. Water samples were distributed into $60 \mathrm{ml}$ BOD bottles (overflowing $>60 \mathrm{ml}$ ) as soon as the Niskin bottles arrived on deck. Three bottles were immediately fixed with Winkler reagents and a further 8 bottles were incubated in darkness at in situ temperature $\left( \pm 1.5^{\circ} \mathrm{C}\right)$. A second set of $11 \mathrm{BOD}$ bottles (3 initials and 8 for incubations) were filled with filtered seawater $(0.8 \mu \mathrm{m}$, low vacuum pressure) from each depth, processed and incubated as described above. Two or 3 BOD bottles were fixed with Winkler reagents after approximately 30 and $48 \mathrm{~h}$. At each timepoint, 1 bottle was processed, as described above, for subsequent determination of bacterial abundance.
Oxygen concentration was titrated with automated Winkler titration technique using a potentiometric end-point detection (Anderson et al. 1992) with an Orion redox electrode (9778-SC) and a custom built titrator. Reagents and standardizations were otherwise similar to those described by JGOFS (1996). The rate of respiration was determined by regressing $\mathrm{O}_{2}$ against time for all 3 timepoints $(0,30$ and $48 \mathrm{~h})$. We used a respiratory quotient of 1 and consider that respiration rates of non-filtered water correspond to community respiration (CR) and respiration of filtered water $(0.8 \mu \mathrm{m})$ correspond to BR. BGE was calculated as $\mathrm{BGE}=\mathrm{BP} /(\mathrm{BP}+\mathrm{BR})$, where $\mathrm{BR}$ was calculated from the incubations described above and BP was determined using the incorporation of leucine in non-filtered water at each depth at the time of sampling.

The integrated values were calculated according to the classical trapezoidal method. All data are reported as mean $\pm \mathrm{SE}$.

\section{RESULTS}

\section{Hydrological and nutrient conditions}

The water column was well stratified in summer and surface temperature reached $25^{\circ} \mathrm{C}$ in August (Fig. 2A). In winter, water was well mixed and temperature was homogeneous with depth $\left(13^{\circ} \mathrm{C}\right)$. The transition periods between stratified and mixed water (and vice versa) occurred in spring (April) and early winter (December). Density was mostly temperature-driven so that isopycnal contours (data not shown) match the isotherms.

Deep water mixing during winter brought up new nutrients into the upper layers. Highest nitrate concentrations were observed in February when all upper water column nitrate concentrations were higher than $1 \mathrm{\mu mol} \mathrm{l}^{-1}$ (Fig. 2B). In contrast, during stratified periods in spring and summer (late April to October), the well-established pycnocline constituted a strong barrier to nutrient replenishment of the surface layers and nitrate concentrations were below $0.5 \mu \mathrm{mol} \mathrm{^{-1 }}$ in the upper (30 to $40 \mathrm{~m}$ ) water column.

\section{Chl a concentration and PP}

High concentrations of nutrients in late winter drove maximum phytoplankton development in early spring. Chl a concentrations were higher than $1.0 \mu \mathrm{g} \mathrm{l}^{-1}$ over the entire water column (5 to $130 \mathrm{~m}$ ) in March and exceeded $1.3 \mu \mathrm{g} \mathrm{l}^{-1}$ between 20 and $110 \mathrm{~m}$ (Fig. 2C). A more modest chl a maximum was also observed in 

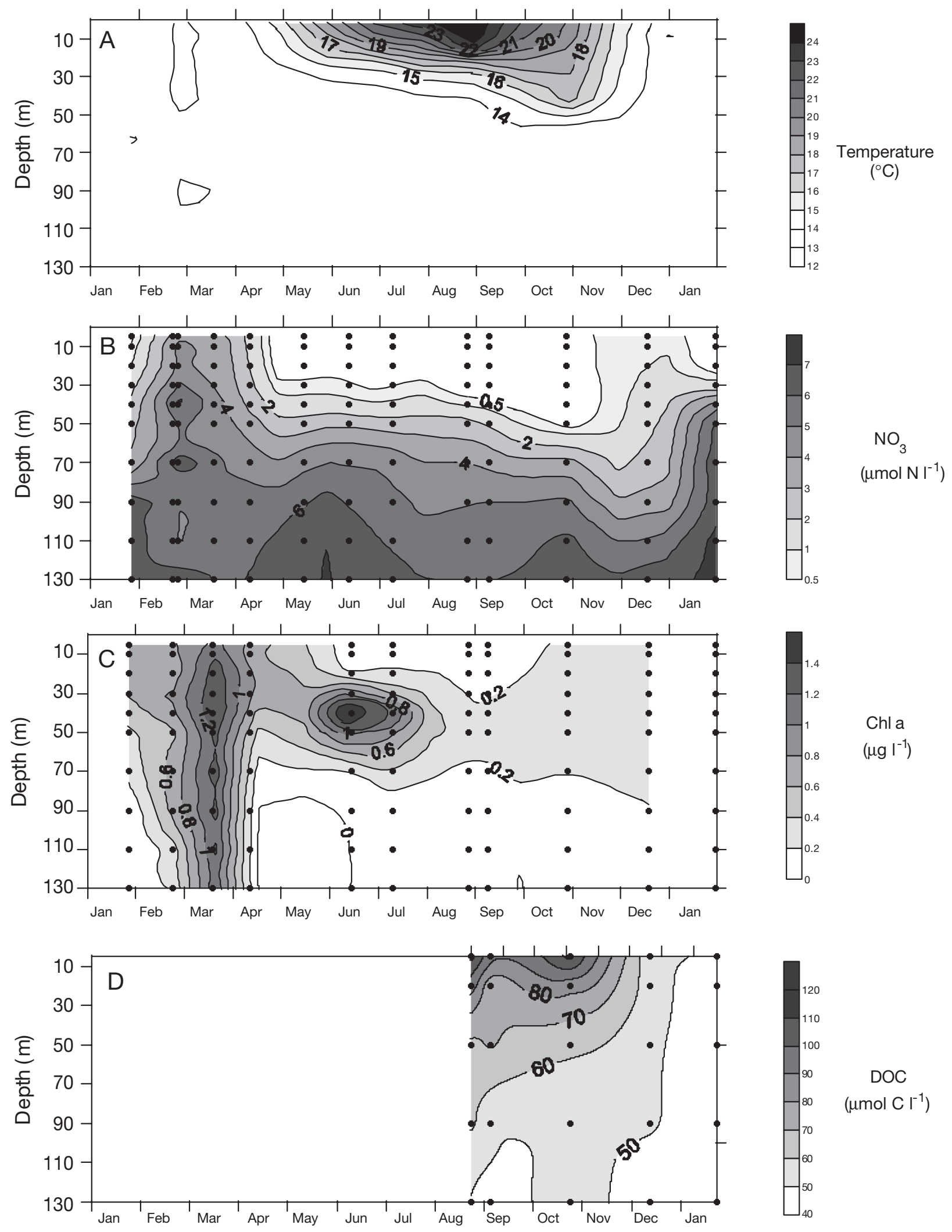

Fig. 2. (A) Temperature, (B) nitrate, (C) chl $a$ and (D) DOC at DYFAMED during the study period (January 1999 to January 2000). Points indicate sampling depths 

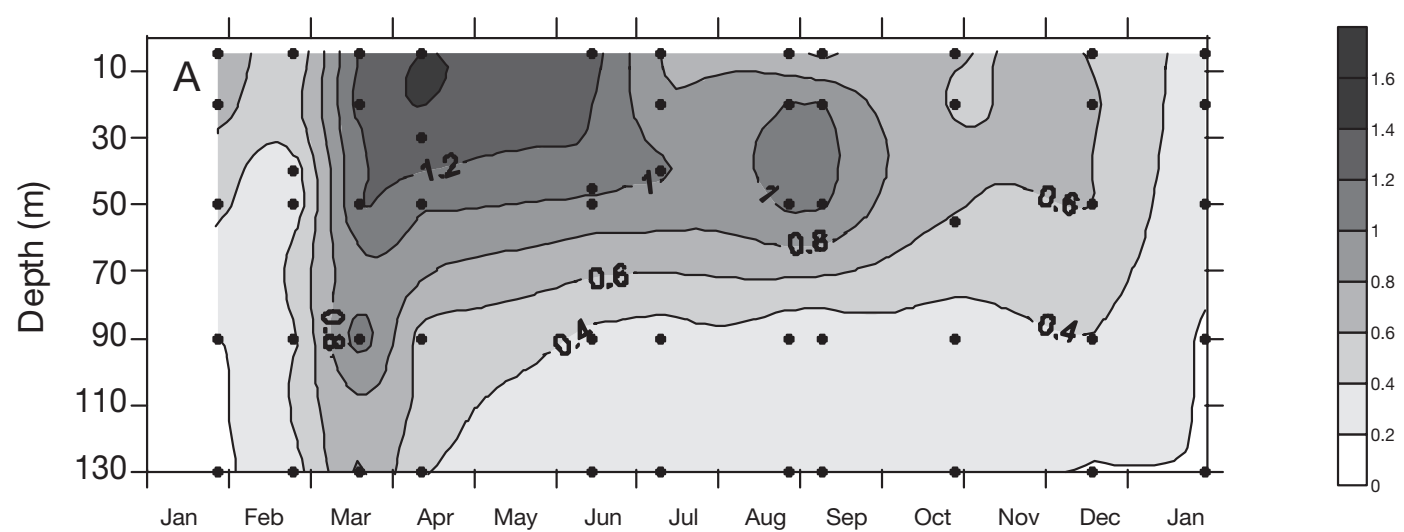

$\mathrm{BB}$
$\left.\mathrm{mol} \mathrm{Cl}^{-1}\right)$
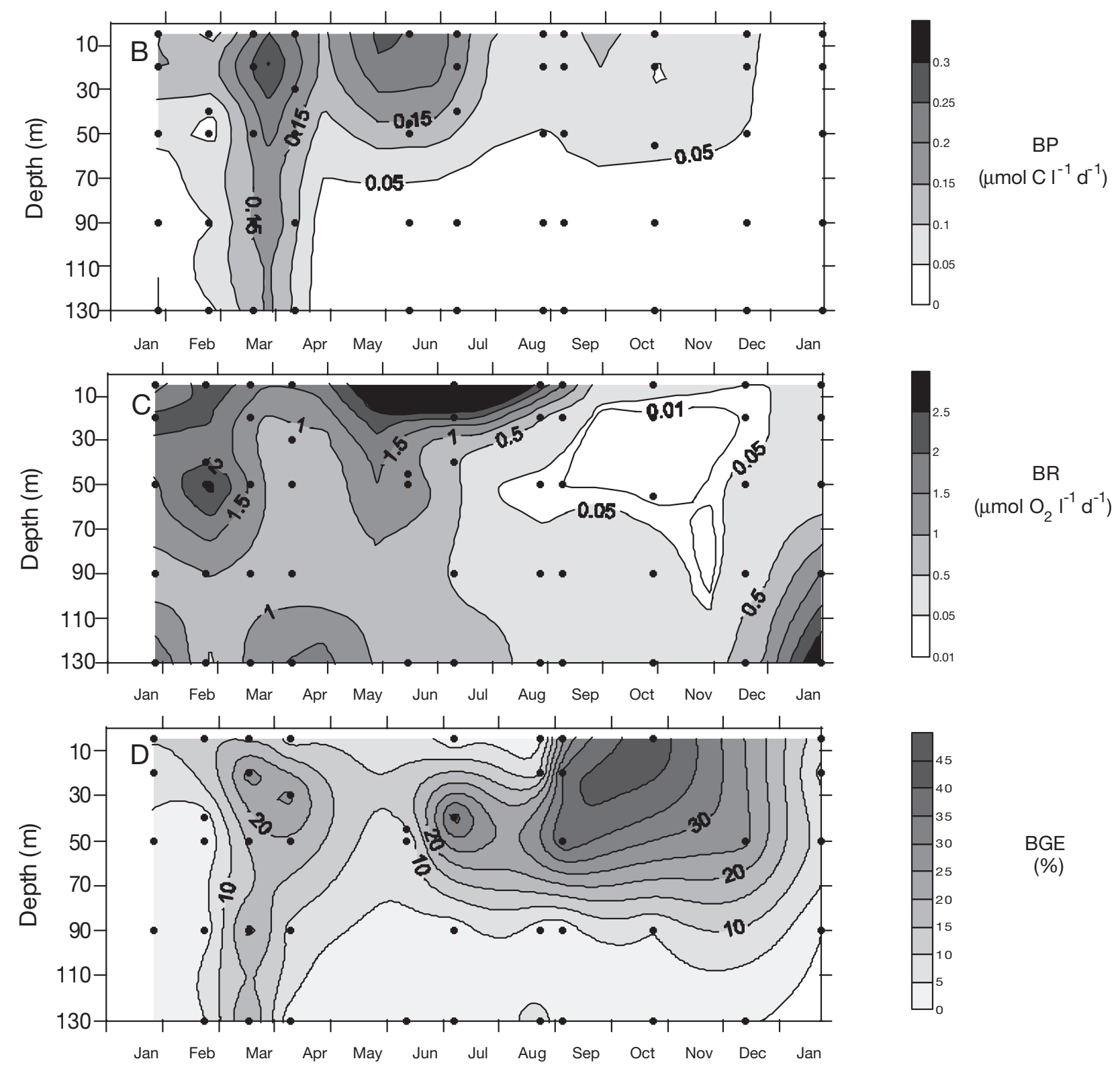

Fig. 3. (A) Bacterial biomass (BB), (B) bacterial production (BP), (C) bacterial respiration (BR) and (D) bacterial growth efficiency (BGE). Points indicate sampling depths 
early summer, with concentrations ranging from 0.9 to $1.9 \mu \mathrm{g} \mathrm{l}^{-1}$ between 30 and $50 \mathrm{~m}$. The lowest chl a concentrations $\left(<0.2 \mu \mathrm{g} \mathrm{l}^{-1}\right)$ were observed in sub-surface water in summer and in deep water (80 to $130 \mathrm{~m}$ ) from June to January.

PP was highest in the surface water (Fig. 4A) at the

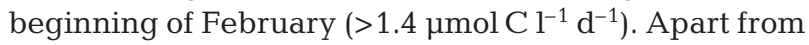
a sub-surface peak in April, PP was less than

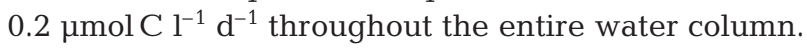

\section{DOC concentration}

There are no data for the first half of the study period (January 1999 to July 1999). In August, surface values were approximately twice that of the deep water (113 vs $49 \mu \mathrm{mol} \mathrm{l^{-1 }}$ ), indicating a net accumulation of DOC in the upper water column (Fig. 2D). From August onwards, DOC concentration decreased in the upper water column to a surface value of $48 \mu \mathrm{mol} \mathrm{l}^{-1}$ in January 2000. There was little change in the concentration of DOC below $60 \mathrm{~m}$ depth throughout the study period and the average concentration of the deeper samples was $50 \pm 2 \mu \mathrm{mol} \mathrm{l} \mathrm{l}^{-1}$.

\section{Bacterial biomass and production}

Bacterial abundance ranged from $1.4 \times 10^{5}{\text { cells } \mathrm{ml}^{-1}}^{-1}$ at $130 \mathrm{~m}$ in January to $1.1 \times 10^{6}$ cells $\mathrm{ml}^{-1}$ in subsurface water in April, corresponding to a $\mathrm{BB}$ of 0.18 and $1.40 \mu \mathrm{mol} \mathrm{C} \mathrm{\textrm {l } ^ { - 1 }}$, respectively (Fig. 3A). The BB maximum was located between 5 and $20 \mathrm{~m}$ during all of the study period, except from July to October, where it varied between 45 and $55 \mathrm{~m}$ depth. BB greater than $0.75 \mu \mathrm{molC} \mathrm{l}^{-1}$ were observed from March to September in the upper $50 \mathrm{~m}$, with maximum values in

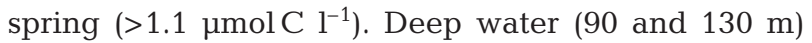
exhibited very low BB (mean $=0.26 \mu$ mol $\mathrm{C}^{-1}$ ) except in March and April, during which values higher than $0.45 \mu \mathrm{mol} \mathrm{C} \mathrm{l}^{-1}$ were observed.

$\mathrm{BP}$ ranged from undetectable at $130 \mathrm{~m}$ depth in January to $0.40 \mu \mathrm{mol} \mathrm{C} \mathrm{l}^{-1} \mathrm{~d}^{-1}$ at $20 \mathrm{~m}$ in March (Fig. 3B). It exhibited a similar evolution to $\mathrm{BB}$, except that: (1) maxima were always measured between 5 and $20 \mathrm{~m}$, even in summer; and (2) highest values $\left(>0.15 \mu \mathrm{mol} \mathrm{C} \mathrm{l}^{-1}\right.$ $\mathrm{d}^{-1}$ ) were observed from March to July. Deep water $(90$ and $130 \mathrm{~m})$ exhibited very low BP (mean $=0.01$

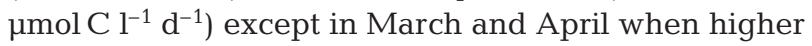

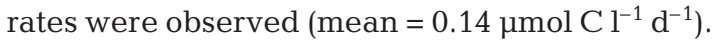
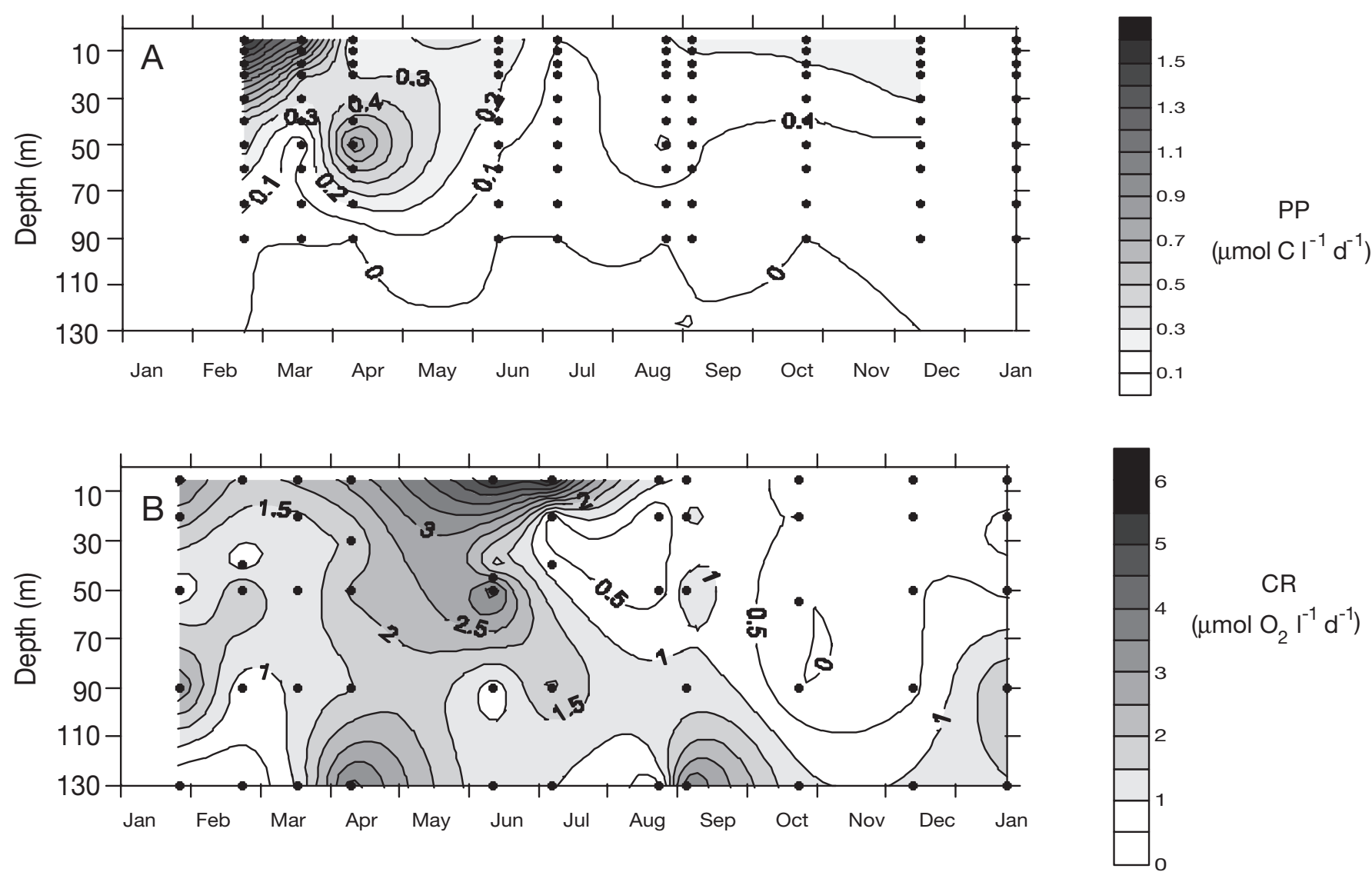

Fig. 4. (A) Primary production (PP) and (B) community respiration (CR). Points indicate sampling depths 


\section{Respiration rates and $\mathrm{BGE}$}

Total CR rates ranged from 0 to $5.9 \mu \mathrm{molO} \mathrm{O}_{2} \mathrm{l}^{-1} \mathrm{~d}^{-1}$ (Fig. 4B). The lowest rates $\left(<0.5 \mu \mathrm{mol} \mathrm{O}_{2} \mathrm{l}^{-1} \mathrm{~d}^{-1}\right)$ were observed in deep water during January and February, at intermediate depths during August and September, and throughout most of the water column from October to December. CR was highest $\left(>1.5 \mu \mathrm{molO} \mathrm{O}_{2} \mathrm{l}^{-1}\right.$ $\mathrm{d}^{-1}$ ) from March to July, with maxima in June and July at $5 \mathrm{~m}$ (5.5 and $5.9 \mu \mathrm{mol} \mathrm{O}_{2} \mathrm{l}^{-1} \mathrm{~d}^{-1}$, respectively). Surface water in January and February 1999 and also some deeper points exhibited rates of respiration higher than $1.5 \mathrm{mmolO}_{2} \mathrm{l}^{-1} \mathrm{~d}^{-1}$. For the whole study period, $75 \%$ of the $\mathrm{CR}$ rates measured were lower than $2 \mu \mathrm{mol} \mathrm{O}_{2} \mathrm{I}^{-1} \mathrm{~d}^{-1}$ with a median of $1.1 \mu \mathrm{mol} \mathrm{O} \mathrm{O}^{-1}$ $\mathrm{d}^{-1}$.

$\mathrm{BR}$ (fraction filtered on $0.8 \mu \mathrm{m}$ ) ranged from 0 to $3.18 \mu \mathrm{mol} \mathrm{O}_{2} \mathrm{l}^{-1} \mathrm{~d}^{-1}$ (Fig. $3 \mathrm{C}$ ). A total of $75 \%$ of the BR rates measured were lower than $1.4 \mu \mathrm{molO} \mathrm{O}_{2} \mathrm{l}^{-1} \mathrm{~d}^{-1}$ with a median of $0.4 \mu \mathrm{molO}_{2} \mathrm{l}^{-1} \mathrm{~d}^{-1}$. From January to July, BR rates exceeded $0.5 \mu \mathrm{mol} \mathrm{O} \mathrm{l}^{-1} \mathrm{~d}^{-1}$, with maxima located below $90 \mathrm{~m}$ in January and February, at 5 and $130 \mathrm{~m}$ in April and below $50 \mathrm{~m}$ from May to July. During the latter period (including $5 \mathrm{~m}$ in August and $130 \mathrm{~m}$ in December), BR accounted for $78 \%$ of total CR $(\mathrm{n}=25, \mathrm{SE}=11$ ). From August to December (excluding $5 \mathrm{~m}$ in August and $130 \mathrm{~m}$ in December), the average BR rate was $0.22 \mu \mathrm{molO} \mathrm{O}_{2} \mathrm{l}^{-1} \mathrm{~d}^{-1}$. During this period, BR accounted for only $33 \%(n=13, \mathrm{SE}=6)$ of total CR ( $\mathrm{n}=$ 11). Overall, BR accounted for $67 \%(n=39, \mathrm{SE}=9)$ of CR.

On average, only $10 \pm 2 \%$ of bacteria were retained on the filters used to prepare the BR size fraction. Although the annual average of the fraction of bacteria passing through the filter did not vary with depth (Fig. 5A), there were some differences between the monthly averages (Fig. 5B): in March, only $66 \pm 3 \%$ of the seawater bacteria were recovered in the filtrate whereas in August, all the bacteria were recovered.

Bacterial abundance generally increased during the incubations. After $48 \mathrm{~h}$, the average increase was $17 \pm$ $4 \%$ for seawater incubations and $16 \pm 5 \%$ for the $<0.8 \mu \mathrm{m}$ size fraction. There were large differences between months and sometimes the number of bacteria decreased during incubation in the $<0.8 \mu \mathrm{m}$ size fraction (Fig. 5C). In 2 of the months studied (July 1999 and January 2000), we saw slight decreases in bacterial abundance during the incubations. This could have been due to the presence of viruses (Fuhrman 1999) or grazing activity, although the latter is unlikely as we used a $0.8 \mu \mathrm{m}$ filter to separate the size fractions, a pore size that should have removed the majority of the grazers in this environment (Tanaka \& Rassoulzadegan 2002).
BGE was calculated using all data except those for which BP or BR was below detection limits (10 data). BGE varied from $0.1 \%$ (January 1999, $90 \mathrm{~m}$ ) to $43 \%$ (October, $5 \mathrm{~m}$ ), with mean and median values of $11 \%$ ( $\mathrm{n}=43, \mathrm{SE}=2$ ) and $7 \%$, respectively, and with $3 / 4$ of the values less than $18 \%$ (Fig. 3D). During January and February, BGE was low throughout the whole water column $(<10 \%)$; it then increased during March and April (>10\% at most depths), reaching a maximum of $26 \%$ in the DCM. In summer, BGE was higher than $10 \%$ at intermediate depths and reached $38 \%$ at $50 \mathrm{~m}$ in July. In the fall, BGE was above $10 \%$ down to a depth of $90 \mathrm{~m}$.
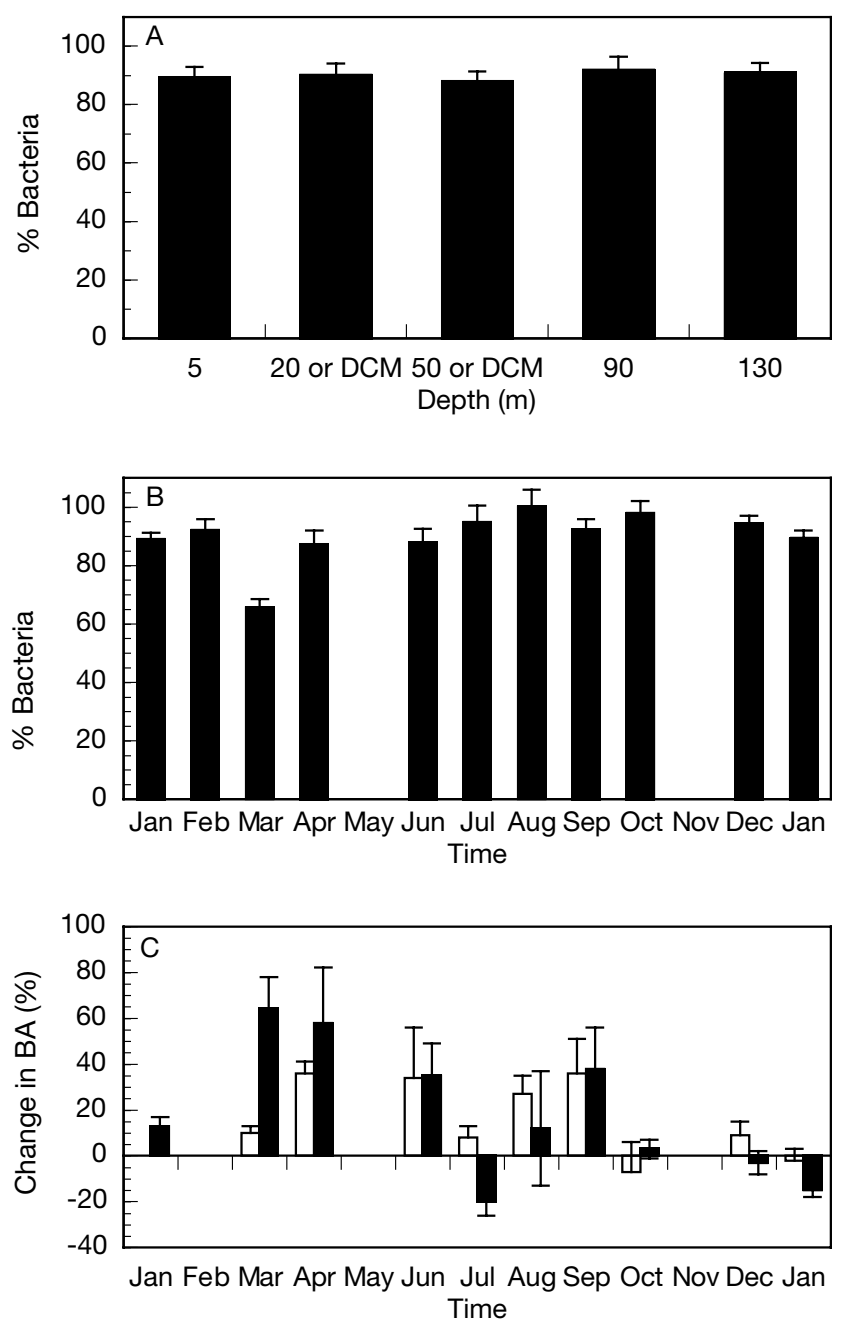

Fig. 5. Percentage of bacteria in the $0.8 \mu \mathrm{m}$ size fraction and changes in bacterial abundance (BA) in the respiration incubations. (A) Average percentage of bacteria in the $0.8 \mu \mathrm{m}$ size fraction at each depth for the whole year. DCM: depth of chloropyll a maximum. (B) Monthly averages of the percentage of bacteria in the $0.8 \mu \mathrm{m}$ size fraction relative to that of unfiltered water. (C) Change in bacterial abundance over the $48 \mathrm{~h}$ of the incubations for both the unfiltered (open bars) and filtered fractions (solid bars) 
Table 1. Integrated values of primary production (PP), community respiration $(\mathrm{CR})$, bacterial production (BP) and bacterial respiration (BR). Data were integrated from 0 to $130 \mathrm{~m}$ depth

\begin{tabular}{|lcccc|}
\hline & $\begin{array}{c}\mathrm{PP} \\
\left(\mathrm{mmol} \mathrm{C} \mathrm{m}^{-2} \mathrm{~d}^{-1}\right)\end{array}$ & $\begin{array}{c}\mathrm{CR} \\
\left(\mathrm{mmol} \mathrm{O}_{2} \mathrm{~m}^{-2} \mathrm{~d}^{-1}\right)\end{array}$ & $\begin{array}{c}\mathrm{BP} \\
\left(\mathrm{mmol} \mathrm{C} \mathrm{m}^{-2} \mathrm{~d}^{-1}\right)\end{array}$ & $\begin{array}{c}\mathrm{BR} \\
\left(\mathrm{mmol} \mathrm{O}_{2} \mathrm{~m}^{-2} \mathrm{~d}^{-1}\right)\end{array}$ \\
\hline Jan & No data & 232 & 8 & 181 \\
Feb & 45 & 137 & 3 & 218 \\
Mar & 26 & 168 & 39 & 162 \\
Apr & 39 & 278 & 9 & 97 \\
Jun & 14 & 489 & 17 & 91 \\
Jul & 5 & 316 & 9 & 144 \\
Aug & 17 & 38 & 4 & 45 \\
Sep & 11 & 201 & 7 & 12 \\
Oct & 9 & 38 & 5 & 13 \\
Dec & 12 & 68 & 5 & 135 \\
Jan & No data & 139 & 1 & \\
\end{tabular}

\section{Depth-integrated PP and CR}

The PP integrated between the surface and $90 \mathrm{~m}$ was highest in February and April, and lowest in the summer and fall (Table 1). The depth-integrated CR exhibited a relatively similar pattern with an additional peak in June and a relatively high value in September.

\section{DISCUSSION}

\section{Trophic status and seasonal changes of biological processes}

The DYFAMED station, situated in the central part of the Ligurian sea, is not influenced by the Ligurian Current. The Liguro-Provencal frontal system (Béthoux et al. 1988) acts as a physical barrier to lateral inputs and limits the influence of the coast. The weakness of horizontal advective movements at this site has recently been confirmed (Andersen \& Prieur 2000) and DYFAMED can be considered as representative of the whole NW Mediterranean Sea (Marty et al. 1994). This area is characterized by a large seasonal variability of hydrological structures, from deep homogenization of the water column in winter to strong stratification in summer. These conditions result in various seasonal trophic regimes from mesotrophic conditions in spring to oligotrophy in summer, with characteristic spring blooms occurring during April and May (Andersen \& Prieur 2000, Vidussi et al. 2000). During our study, an early bloom occurred in March and was followed by a deep $(40 \mathrm{~m}) \mathrm{chl}$ a maximum during the summer stratification.

The various hydrologic and trophic regimes observed over a year at DYFAMED led to a great variation of bacterial activity. From the pre-bloom period to early summer, and with a negative gradient from sub-surface to maximum depth of sampling, bacterial parameters seem to follow each other, i.e. maximum respiration in February, maximum production in March and maximum biomass in April.

The fraction of the bacterial community passing through the $0.8 \mu \mathrm{m}$ porosity membrane (for BR measurements) also exhibited seasonal changes. It ranged from $66 \%$ in March to $100 \%$ in August. Two hypotheses could explain this difference: (1) a seasonal change in bacterial cell size, with larger bacteria in the bloom period; or (2) a seasonal change in the fraction of free and attached bacteria. Since the BR was measured on the filtered fraction, it is likely that its estimate was good in summer but probably underestimated in March, implying an overestimation of BGE in this month.

Diel variations were not taken into account in our study since we collected samples at the same hour $( \pm 2 \mathrm{~h})$ each month. Our aim was to study bacterial processes at a seasonal scale, with samples collected monthly. Nevertheless, processes measured in a sample collected once a month may not exactly reflect the monthly mean of the processes. This has already been demonstrated at DYFAMED, since BB and BP can exhibit large changes over a few days, especially in post bloom period (Van Wambeke et al. 2001).

Assuming a conversion factor of $15 \mathrm{fg} \mathrm{C}$ per bacteria, $\mathrm{BB}$ in our study is in agreement with those reported in the literature for the open NW Mediterranean, which ranged from 0.23 to $1.6 \mu \mathrm{mol} \mathrm{C}{ }^{-1}$ (e.g. Fernandez et al. 1994, Van Wambeke et al. 1996, Tanaka \& Rassoulzadegan 2002). Values of BP (ranging from unde-

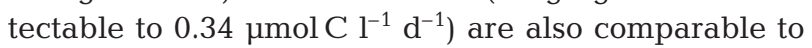
those already measured at DYFAMED or in other parts of Mediterranean (Conan et al. 1999, Van Wambeke et al. 2001).

\section{Regulation of BGE}

BGE ranged from less than $1 \%$ to more than $40 \%$ throughout the study period, and were within the ranges observed by other researchers in oligotrophic and oceanic sites (Carlson \& Ducklow 1996). Many factors, such as temperature and availability of inorganic nutrients and DOC, can potentially control BGE. Although temperature appears to have little effect on BGE in our data set, BGE is negatively correlated with $\mathrm{NO}_{3}(\mathrm{r}=-0.54, \mathrm{p}<0.01)$ and $\mathrm{PO}_{4}(\mathrm{r}=-0.63, \mathrm{p}<0.01)$, 
and positively correlated with DOC $(\mathrm{r}=0.50, \mathrm{p}<0.05)$ and chl a $(\mathrm{r}=0.32, \mathrm{p}<0.05)$. It is surprising that relatively high concentrations of $\mathrm{PO}_{4}$ would lead to lower BGE because the Mediterranean Sea is generally considered to be P limited (e.g. Thingstad \& Rassoulzadegan 1995). There is, therefore, another factor involved in the control of BGE at this site, perhaps DOM quality (Biddanda et al. 1994, Carlson \& Ducklow 1996).

Although these correlations permit us to predict when we would see elevated BGE, it does not really identify the regulatory mechanisms. The equation for calculating BGE is comprised of 2 parameters (BR and $\mathrm{BP})$, either of which can be responsible for changes in BGE. There is no significant relationship between BR and any of the physical or chemical parameters measured, with the exception of chl a. This suggests that $\mathrm{BR}$ is controlled by either another unmeasured factor, or is controlled at a timescale (i.e. sub-monthly), which has not been addressed in this data set. It seems that BR was not directly influenced by temperature, contrary to the conclusions of Rivkin \& Legendre (2001).

The lack of correlation between BR and the other parameters could be in part due to the probable underestimation of BP in March. However, this only concerns 5 data and cannot fully account for the lack of correlation. Conversely, BP was highly correlated with $\mathrm{NO}_{3}$, $\mathrm{PO}_{4}$, DOC and chl $a$, which suggests that it is BP rather than BR that is varying in response to changes in these environmental parameters.

Interestingly, although the correlations between BP and DOC and chl a were positive, the correlations between BP and inorganic nutrients were negative. It is probable that these parameters themselves are not directly influencing BP but are exerting an influence on the accumulation of DOC and chl $a$. This is intuitive when one examines the depletion of inorganic nutrients corresponding to the increase in chl $a$ and DOC. del Giorgio \& Cole (1998) proposed that the variability of BGE is probably not so much explained by 1 single factor but by a combination of factors. Given the relatively large seasonal changes in environmental parameters experienced at DYFAMED, it is improbable that 1 single factor controls BGE at all depths and throughout the entire season. Indeed, recently, Van Wambeke et al. (2002) found that in the fall, BP at DYFAMED appears to be limited by phosphorus in the upper $40 \mathrm{~m}$ and by carbon below $40 \mathrm{~m}$.

\section{Autotrophy versus heterotrophy}

The rates of ${ }^{14} \mathrm{C} P P\left(0\right.$ to $1.6 \mathrm{mmol} \mathrm{C} \mathrm{m}^{-2} \mathrm{~d}^{-1}$ ) are within the range of data reported in the literature in the NW Mediterranean Sea (0 to $5.6 \mathrm{mmol} \mathrm{C} \mathrm{m}{ }^{-2} \mathrm{~d}^{-1}$; Lefèvre et al. 1994, Conan et al. 1999, Diaz et al. 2001).
The rates of CR at depths lower than $130 \mathrm{~m}$ (range of 0 to 3.18 and average of $0.8 \mathrm{mmol} \mathrm{O}_{2} \mathrm{~m}^{-2} \mathrm{~d}^{-1}$ ) are also in good agreement with published values for the Mediterranean Sea (range between -1 and 4.5 and average value of $0.7 \mathrm{mmol} \mathrm{O}_{2} \mathrm{~m}^{-2} \mathrm{~d}^{-1}$; e.g. Williams \& Robinson 1990, 1992, Savenkoff et al. 1992, 1993, Lefèvre et al. 1994, 1996, Agustí et al. 1998). The rates of ${ }^{14} \mathrm{C} \mathrm{PP}$ are significantly lower than the rates of $\mathrm{CR}$ whether expressed in volumetric $\left(\mu \mathrm{mol} \mathrm{l^{-1 }} \mathrm{d}^{-1}\right)$ or depth-integrated $\left(\mathrm{mmol} \mathrm{m} \mathrm{m}^{-2} \mathrm{~d}^{-1}\right)$ units.

The status of oligotrophic areas in terms of carbon balance has been the subject of considerable controversy. del Giorgio et al. (1997) have suggested that aquatic ecosystems exhibiting rates of ${ }^{14} \mathrm{C} \mathrm{PP}$ lower than $8.3 \mu \mathrm{mol} \mathrm{C} \mathrm{l}^{-1} \mathrm{~d}^{-1}$ are net heterotrophic (PP lower than CR). This conclusion was supported by Duarte \& Agusti (1998) who examined the balance between heterotrophy and autotrophy in a range of environments, and concluded that there was evidence of net heterotrophy in the upper ocean. This was subsequently challenged by Williams (1998) who could not find any evidence of this in his analyses of the balance between net heterotrophy and net autotrophy in open ocean regions. Over and above the problems associated with the numerical analysis of the $\mathrm{P}$ versus $\mathrm{R}$ relationship (Williams \& Bowers 1999), there are also several methodological reasons that render the estimation of metabolic status difficult. It is beyond the scope of the present paper to review these reasons, and so we will just list the major ones.

Most techniques used to estimate $\mathrm{PP}$ and respiration involve incubation of water samples. Containment potentially changes the original pelagic community, for example by excluding the predators of microzooplankton, which then graze phytoplankton at a higher rate.

The ${ }^{14} \mathrm{C}$ technique is the most popular method used to estimate PP because it is relatively easy to use. However, it is unknown whether it measures net or gross PP because some of the radiolabel incorporated in photosynthates can subsequently be respired (Peterson 1980). The rates measured are close to gross PP when short (typically a few hours) incubations are used and close to net PP when longer (typically $12 \mathrm{~h}$ or more) incubations are used. Furthermore, the standard ${ }^{14} \mathrm{C}$ technique (JGOFS 1996) only measures the incorporation of carbon into particulate matter $\left({ }^{14} \mathrm{C}\right.$ POC). However, some of the carbon fixed can leak from phytoplanktonic cells as dissolved organic matter $\left({ }^{14} \mathrm{C}\right.$-DOC), with the result that the total PP can be significantly underestimated. Recent data collected in the subtropical North Pacific Ocean demonstrate that ${ }^{14} \mathrm{C}$-DOC can be nearly $50 \%$ of ${ }^{14} \mathrm{C}$-POC (Karl et al. 1998) and in the SW Mediterranean sea dissolved PP can represent 4 to $44 \%$ of total PP (Morán \& Estrada 2001). 
The sensitivity of the oxygen technique is lower than that of the ${ }^{14} \mathrm{C}$ technique. Consequently incubations must be longer and measurements of CR in oligotrophic areas usually last for 24 to $48 \mathrm{~h}$. This can lead to a large increase in the bacterial population (Pomeroy et al. 1994) and to changes in the bacterial community composition (Massana et al. 2001, Gattuso et al. in press).

An additional difficulty arises when PP and respiration are measured using different techniques. Metabolic quotients must then be used to express the processes in similar units in order to compare them. These quotients are not often measured and their values are not well constrained. The photosynthetic quotient (PQ: mole of $\mathrm{O}_{2}$ released per mole of $\mathrm{CO}_{2}$ fixed) varies as a function of $\mathrm{O}_{2}$ and $\mathrm{CO}_{2}$ concentration, nitrogen availability, photosynthate quality and light intensity (see Williams et al. 1979, Gattuso \& Jaubert 1988). A PQ value of 1.25 is often assumed. The respiratory quotient (RQ: mole of $\mathrm{CO}_{2}$ released per mole of $\mathrm{O}_{2}$ consumed) varies essentially as a function of the quality of the organic matter catabolized (Gnaiger 1983) and ranges between 0.7 and 1.0 .

Assuming that $\mathrm{PQ}=1.25$ and that ${ }^{14} \mathrm{C}$-DOC is $50 \%$ of ${ }^{14} \mathrm{C}$-POC, the ratio of depth-integrated PP versus $\mathrm{CR}$ at the DYFAMED site ranges from 0.1 to 1.1 . This suggests that it was net autotrophic in February and August, and net heterotrophic during the remaining months. All the ${ }^{14} \mathrm{C}$ PP measured at DYFAMED during the study period are lower than the threshold value of $8.3 \mu \mathrm{mol} \mathrm{C} \mathrm{m} \mathrm{C}^{-1}$ suggested by del Giorgio et al. (1997). Our data seem therefore to support their conclusion that oligotrophic systems are net heterotrophic. However, as mentioned above, our estimates involve many assumptions (fixed PQ and percent ${ }^{14} \mathrm{C}$-DOC PP) and must be considered as preliminary.

Our study only considered the balance between respiration and photosynthesis in the upper $130 \mathrm{~m}$. In the deeper waters, where there is no PP and degradation of organic matter dominates, clearly the respiration processes will accentuate the water column $\mathrm{CO}_{2}$ budget and so render this environment even more heterotrophic. The probable decoupling between production in the surface layers and degradation deep layers further complicates the development of an integrated carbon budget in this system.

Acknowledgements. Thanks are due to A. Stock as well as the Captain and crew of the RV 'Tethys II' for invaluable help in the field. J. Chiaverini and J.-C. Marty kindly provided chlorophyll $a$ and primary production data. We also wish to thank 2 anonymous reviewers for their helpful comments. Funding was provided by a CNRS ATIPE grant. This is a contribution of the DYFAMED project, a France-JGOFS initiative.

\section{LITERATURE CITED}

Agustí S, Satta MP, Mura MP, Benavent E (1998) Dissolved esterase activity as a tracer of phytoplankton lysis: evidence of high phytoplankton lysis rates in Northwestern Mediterranean. Limnol Oceanogr 43:1836-1849

Andersen V, Prieur L (2000) One-month study in the open NW Mediterranean Sea (DYNAPROC experiment, May 1995): overview of the hydrobiological structures and effects of wind events. Deep-Sea Res I 47:397-422

Anderson LG, Haraldsson C, Lindegren R (1992) Gran linearization of potentiometric Winkler titration. Mar Chem 37:179-190

Béthoux JP, Prieur L, Bong JH (1988) Le courant Ligure au large de Nice. Oceanol Acta 9:59-67

Biddanda B, Opsahl S, Benner R (1994) Plankton respiration and carbon flux through bacterioplankton on the Louisiana Shelf. Limnol Oceanogr 39:1259-1275

Carlson CA, Ducklow HW (1996) Growth of bacterioplankton and consumption of dissolved organic carbon in the Sargasso Sea. Aquat Microb Ecol 10:69-85

Caron DA, Dam HG, Kremer P, Lessard EJ and 6 others (1995) The contribution of micro-organisms to particulate carbon and nitrogen in surface waters of the Sargasso Sea near Bermuda. Deep-Sea Res I 42:943-972

Cole JJ, Pace ML (1995) Why measure bacterial production? A reply to the comment by Jahnke and Craven. Limnol Oceanogr 40:441-444

Conan P, Turley C, Stutt E, Pujo-Pay M, Van Wambeke F (1999) Relationship between phytoplankton efficiency and the proportion of bacterial production to primary production in the Mediterranean Sea. Aquat Microb Ecol 17:131-144

Copin-Montégut C, Copin-Montégut G (1983) Stoichiometry of carbon, nitrogen, and phosphorus in marine particulate matter. Deep-Sea Res 30:31-46

Dandonneau Y, Le Bouteillier A (1992) A simple and rapid device for measuring planktonic primary production by in situ sampling, and ${ }^{14} \mathrm{C}$ injection and incubation. Deep-Sea Res 39:795-803

del Giorgio PA, Cole JL (1998) Bacterial growth efficiency in natural aquatic systems. Annu Rev Ecol Syst 29:503-541

del Giorgio PA, Cole JJ, Cimbleris A (1997) Respiration rates in bacteria exceed phytoplankton production in unproductive aquatic systems. Nature 385:148-151

Diaz F, Raimbault P, Boudjellal B, Garcia N, Moutin T (2001) Early spring phosphorus limitation of primary productivity in a NW Mediterranean coastal zone (Gulf of Lions). Mar Ecol Prog Ser 211:51-62

Duarte CM, Agustí S (1998) The $\mathrm{CO}_{2}$ balance of unproductive aquatic ecosystems. Science 281:234-236

Fernandez M, Bianchi M, Van Wambeke F (1994) Bacterial biomass, heterotrophic production and utilization of dissolved organic matter photosynthetically produced in the Almeria-Oran front. J Mar Syst 5:313-325

Fuhrman JA (1999) Marine viruses and their biogeochemical and ecological effects. Nature 399:541-548

Gattuso JP, Jaubert J (1988) Computation of metabolic quotients in plant-animal symbiotic units. J Theor Biol 130: 205-212

Gattuso JP, Peduzzi S, Pizay MD, Tonolla M (in press) Changes in bacterial community composition during measurements of microbial and community respiration. J Plankton Res

Gnaiger E (1983) Calculation of energetic and biochemical equivalents of respiratory oxygen consumption. In: Gnaiger E, Forstner H (eds) Polarographic oxygen sensors: aquatic and physiological applications, Appendix C. 
Springer-Verlag, Berlin, p 337-345

Griffin PC, Pomeroy LR (1995) Seasonal and spatial variations in pelagic community respiration on the south eastern U.S. continental shelf. Cont Shelf Res 15:815-825

Jahnke RA, Craven DB (1995) Quantifying the role of heterotrophic bacteria in the carbon cycle: a need for respiration rate measurements. Limnol Oceanogr 40(2):436-441

JGOFS (Joint Global Ocean Flux Study) (1996) Protocols for the JGOFS core measurements. In: Knap A, Michaels A, Close A, Ducklow H, Dickson A (eds) JGOFS Rep No. 19. Reprint of the Intergovernmental Oceanographic Commission Manuals and Guides (1994) No. 29, Bergen

Karl DM, Hebel DV, Bjökman K, Letelier RM (1998) The role of dissolved organic matter release in the productivity of the oligotrophic North Pacific Ocean. Limnol Oceanogr 43:1270-1286

Kirchman DL (1993) Leucine incorporation as a measure of biomass production by heterotrophic bacteria. In: Kemp PF, Sherr BF, Sherr EB, Cole JJ (eds) Handbook of methods in aquatic microbial ecology. Lewis, Boca Raton, p 509-512

Kirchman DL, K'nees E, Hodson R (1985) Leucine incorporation and its potential as a measure of protein synthesis by bacteria in natural aquatic ecosystems. Appl Environ Microbiol 49:599-607

Lefèvre D, Bentley TL, Robinson C, Blight SP, Williams PJLeB (1994) The temperature response of gross and net community production and respiration in time-varying assemblages of temperate marine micro-plankton. J Exp Mar Biol Ecol 184:201-215

Lefèvre D, Denis M, Lambert CE, Miquel JC (1996) Is DOC the main source of organic matter remineralization in the ocean water column? J Mar Syst 7:281-291

Marty JC, Nicolas JC, Miquel JC, Fowler SC (1994) Particulate fluxes of organic compounds and their relationship to zooplankton fecal pellets in the northwestern Mediterranean Sea. Mar Chem 46:387-405

Massana R, Pedrós-Alió C, Casamayor EO, Gasol JM (2001) Changes in marine bacterioplankton phylogenetic composition during incubations designed to measure biogeochemically significant parameters. Limnol Oceanogr 46: 1181-1188

Morán XAG, Estrada M (2001) Short-term variability of photosynthetic parameters and particulate and dissolved primary production in the Alboran Sea (SW Mediterranean). Mar Ecol Prog Ser 212:53-67

Moutin T, Raimbault P, Poggiale JC (1999) Primary production in surface waters of the western Mediterranean sea. Calculation of daily production. CR Acad Sci Paris 322: 651-659

Peterson BJ (1980) Aquatic primary productivity and the ${ }^{14} \mathrm{C}$ $\mathrm{CO}_{2}$ method: a history of the productivity problem. Annu Rev Ecol Syst 11:359-385

Pomeroy LR, Wiebe WJ (1993) Energy sources for microbial food webs. Mar Microb Food Webs 7:101-118

Pomeroy LR, Sheldon JE, Sheldon WMJ (1994) Changes in bacterial numbers and leucine assimilation during estimations of microbial respiratory rates in seawater by the precision Winkler method. Appl Environ Microbiol 60: 328-332

Porter KG, Feig TS (1980) The use of DAPI for identifying and counting aquatic microflora. Limnol Oceanogr 25: 943-948

Rivkin RB, Legendre L (2001) Biogenic carbon cycling in the upper ocean: effects of microbial respiration. Science 291: $2398-2400$

Savenkoff C, Da Silva NL, Lefèvre D, Denis M, Rassoulzadegan F (1992) Contribution of the different planktonic microbial assemblages to ETS activity in the Ligurian frontal area: northwestern Mediterranean Sea. J Plankton Res 14:835-850

Savenkoff C, Prieur L, Reys JP, Lefevre D, Dallot S, Denis M (1993) Deep microbial communities evidenced in the Liguro-Provencal front by their ETS activity. Deep-Sea Res 40:709-725

Tanaka T, Rassoulzadegan F (2002) Full-depth profile $(0-2000 \mathrm{~m})$ of bacteria, heterotrophic nanoflagellates and ciliates in the NW Mediterranean Sea: vertical partitioning of microbial trophic structures. Deep-Sea Res II 49:2093-2107

Thingstad TF, Rassoulzadegan F (1995) Nutrient limitations, microbial food webs, and 'biological C-pumps': suggested interactions in a P-limitated Mediterranean. Mar Ecol Prog Ser 117:299-306

Tréguer P, Le Corre P (1975) Manuel d'analyse des sels nutritifs dans l'eau de mer (utilisation de l'AutoAnalyzer Technicon $\left.{ }^{\circledR}\right)$, 2nd edn. Université de Bretagne Occidentale, Brest

Van Wambeke F, Christaki U, Gaudy R (1996) Carbon fluxes from the microbial food web to mesozooplankton. An approach in the surface layer of a pelagic area (NW Mediterranean Sea). Oceanol Acta 19:57-66

Van Wambeke F, Goutx M, Striby L, Sempéré R, Vidussi F (2001) Bacterial dynamics during the transition from spring bloom to oligotrophy in the Northwestern Mediterranean Sea: relationships with particulate detritus and dissolved organic matter. Mar Ecol Prog Ser 212:89-105

Van Wambeke F, Christaki U, Giannakourou A, Moutin T, Souvemerzoglou K (2002) Longitudinal and vertical trends of bacterial limitation by phosphorus and carbon in the Mediterranean Sea. Microb Ecol 43:119-133

Vidussi F, Claustre H, Bustillos-Guzman J, Cailliau C, Marty JC (1996) Determination of chlorophylls and carotenoids of marine phytoplankton: separation of chlorophyll a from divinyl-chlorophyll a and zeaxanthin from luthein. J Plankton Res 18:2377-2382

Vidussi F, Marty JC, Chiaverini J (2000) Phytoplankton pigment variations during the transition from spring bloom to oligotrophy in the Northwestern Mediterranean sea. Deep-Sea Res I 47:423-445

Williams PJLeB (1998) The balance of plankton respiration and photosynthesis in the open oceans. Nature 394:55-57

Williams PJLeB, Bowers DG (1999) Regional carbon imbalances in the oceans. Science 284:1735

Williams PJLeB, Robinson C (1990) Seasonal differences in the control of productivity in the Rhone outfall region of the Gulf of Lions. In: Martin JM, Barth H (eds) Water pollution research reports 'EROS 2000'. Commission of the European Communities, Brussels, Vol 20, p 145-154

Williams PJLeB, Robinson C (1992) Analysis of oxygen-based productivity measurements through phase I of the EROS 2000 programme. In: Martin JM, Barth H (eds) Water pollution research reports 'EROS 2000'. Commission of the European Communities, Brussels, Vol 28, p 151-162

Williams PJLeB, Raine RCT, Bryan JR (1979) Agreement between the ${ }^{14} \mathrm{C}$ and oxygen methods of measuring phytoplankton production: reassessment of the photosynthetic quotient. Oceanol Acta 2:411-416

Submitted: January 11, 2002; Accepted: June 7, 2002

Proofs received from author(s): September 12, 2002 